\title{
TWIST1 wt Allele
}

National Cancer Institute

\section{Source}

National Cancer Institute. TWIST1 wt Allele. NCI Thesaurus. Code C53115.

Human TWIST 1 wild-type allele is located in the vicinity of 17p13.3 and is approximately $16 \mathrm{~kb}$ in length. This allele, which encodes twist-related protein 1, plays a role in the regulation of both transcription and cell lineage determination. Mutations in the gene are associated with Saethre-Chotzen, Robinow-Sorauf, and Baller-Gerold syndromes. 